\title{
Exploring the Implementation of Student-centered Learning in EFL Classrooms: Perspectives from Islamic Secondary-school Teachers in Indonesia
}

\author{
Miftahul Huda \\ Universitas Pendidikan Indonesia \\ Email:miftahulh@gmail.com
}

\author{
Arif Husein Lubis \\ Universitas Pendidikan Indonesia \\ Email:lubis_ah@yahoo.com
}

\begin{abstract}
:
One notable goal of the $21^{\text {st }}$-century pedagogy is the encouragement for the students to be the agent of change in their own learning process realized by the implementation of student-centered learning approach (SCL). However, previous literature noted the discrepancy between what they believe in and what they perform in the classroom. Thus, this descriptive qualitative study aims to extend the study from the perspectives of Indonesian Islamic secondary-school EFL teachers, specifically investigating their perceptions on SCL, preferences of using SCL strategies, and challenges in implementing it. Of nine teachers, four teachers were willing to participate purposively based on their background. Data were collected by using a questionnaire and a followup interview. After filling in the questionnaire, four teachers were selected to participate in the follow-up interview. Three major findings were obtained. They have been aware of the importance of SCL, although most of their students were still passive. As a result, they preferred to combine the lecture and the student-centered activities like role-play, simulation, cooperative learning, and problem-based learning. However, they did not regularize the facilitation of individual or group presentation. With respect to the challenges, the interview data disclosed that the teachers encountered the limited allocated time to maximize SCL implementation, students' passivity and self-confidence deterioration leading to limited responses and meaningful communication, and lack of training in implementing SCL-based assessment. This study provides an insight into the
\end{abstract}


reality of SCL implementation in EFL classroom settings from Islamic secondary-school teachers. Recommendations for further studies are also discussed.

Keywords: 2013 Curriculum, Islamic school EFL teachers, perceptions, student-centered learning

\section{Introduction}

In English as a foreign language teaching and learning, methods, approaches, and techniques are exponentially developing to meet one of the increasing demands, i.e. making the students more autonomous and self-driven in developing their own skills including in English education. One notable realization is through Student-Centered Learning (hereafter SCL) that is perceived useful in the rapidly evolving educational environment (Al-Humaidi, 2015).

The practice of 2013 Curriculum (K-13) in Indonesia for English lesson highlights a clear direction of teaching and learning process from teacher-centered to student-centered. It is to enhance the students' communicative competence as the goal of teaching English. In addition, the use of scientific approach encourages the realization of the new direction for the sake of the students' critical thinking development. It is assumed that teaching and learning process includes some dialogic activities from questioning to communicating. Such a process will possibly result in the development of students' critical thinking.

However, some previous research has noted the challenges in implementing the principles of 2013 Curriculum as the latest curriculum in Indonesia, which emphasize student-centered learning. A research conducted by Nur and Madkur (2014) analyzed the implementation of K13 encompassing the teachers' perspectives on their experiences in implementing the curriculum, challenges, and opportunities in Bogor and Lampung. The findings showed that although most of the teachers accepted the enforcement of the curriculum, they felt like experiencing a culture shock because their schools were selected as the piloting sites by the government. Regarding the perception, the participating teachers agreed that the key of this implementation is on the teachers' openness and innovativeness to achieve the expected teaching and learning process.

Previous literature also unpacked that most high-school students hardly have the opportunity to practice their English in the real world circumstances for simple purposes. It contrasts to the mandated standardized English competences. Some factors account for the problems. Wachidah (2013) asserted that the learning process is actually still teacher-driven. The learning process highly relies on the teacher's explanation, teacher-directed practice, and homework. In other words, they perform more passivity in the classroom and dependency on the teacher's instructions.

Al-Humaidi (2015) also found a paradox between the teachers' perceptions and their actual practices in implementing the SCL. Lee (2009) also found that although many teachers were 
aware of the significance of using student-centered approach, textbooks were still preferred to be the only learning source.

On the basis of the issue explained before, thus, the present study attempts to explore how the local teachers view SCL approach and how they maintain the approach in their daily practice of teaching English through their perception. To obtain adequate information to achieve the purpose, this study is driven by the following questions.

1. How do the English language teachers perceive SCL?

2. What kind of SCL strategy do they apply?

3. What are the challenges in realizing the SCL approach?

By doing so, this study may extend the myths and realities of the SCL implementation in EFL classroom settings from the perspectives of Islamic secondary school teachers, which has received little attention. In addition, this study may be a useful resource for both teachers and practitioners in the curriculum evaluation process as the agent of SCL approach implementation.

The following section elaborates on the theoretical views that become the bases for exploring the issue. It encompasses the characteristics of SCL as a contemporary approach to teach foreign language and the elements of SCL implementation in the classroom.

\section{Literature Review}

\subsection{The Conception of Student-Centered Learning from Constructivism Pedagogy Perspective}

The concept of student-centered learning is coined from the four most important learning philosophies, i.e. Progressive Education, Humanistic Psychology, Constructivism, and SocioCultural Theory (Jacobs \& Renandya, 2016). However, two of them become the most influential underlying paradigms. First, it is the Jean Jacques Rousseau's conception of progressive education, who promoted childhood self-expression. It is believed that when children can express something by themselves, the opportunity to promote creativity and freedom for their own learning development can be gained.

Second, it is the John Dewey's advocacy of student-centered curricula. It aims to establish a curriculum that integrates the subject matter with the students' interests and needs. Furthermore, he attempted to emphasize the students' needs as the basis for conducting the learning process.

Therefore, SCL can be implemented by the manifestation of contemporary and socioconstructive teaching methods which aim to promote the students to be active agents for their own learning. One of the ways is by fostering the transferrable skills such as problem solving, critical thinking, and reflective thinking. Other aspects of SCL include active learning, continuous self-reflection, cooperative learning atmosphere, promotion of higher-order thinking skills, self-regulatory learning, and diverse students' background. 
In the process of realization of the socio-constructive teaching methods, teachers can employ some of the useful activities including interactive lecturing, class/online discussion, case studies, discovery learning, simulations, and role-plays. Moreover, individual or group projects may be done through paper writing, essays, and reports, within a research-oriented process. To be more specific, Al-Humaidi (2015) has depicted some of the SCL characteristics differing from TCL.

Table 1. Differences between SCL and TCL

\begin{tabular}{ll}
\hline Student-centered Learning & Teacher-centered Learning \\
\hline Self-regulated learning & Teacher-driven \\
$\begin{array}{l}\text { More students' participation } \\
\text { More students' power }\end{array}$ & More passivity \\
$\begin{array}{l}\text { Appreciation to students' diverse background knowledge } \\
\text { and skill }\end{array}$ & $\begin{array}{l}\text { More teacher's control } \\
\text { Unification of the perceived } \\
\text { students' background knowledge }\end{array}$ \\
Dialogic negotiation of the learning routes with the teacher & Rigid and formal learning routes \\
Encouragement on self-exploration & Textbook-driven \\
Authentic formative and summative assessment & Test-oriented assessment \\
Self-note taking & $\begin{array}{l}\text { Provision of the notes by the } \\
\text { teacher }\end{array}$ \\
Critical discussion to understand the materials & Spoon-feeding activity \\
Active questions and answers & Less questions and answers \\
\hline
\end{tabular}

The concept of SCL is stipulated in 2013 Curriculum through the Regulations of MOEC of Indonesia No. 81A. It mandates the learning shifts from one way to student-teacher and student-student interactions. In addition, student-centered learning embraces the concept of students' choices in their education; in their learning activities (active vs. passive learning); and in their power relationship with the teachers.

\subsection{The Elements of Student-Centered Learning}

It is worth discussing then about what contributing elements that must be included in the student-centered learning approach. Jacobs and Renandya (2016) provide a summary of the ten elements of SCL as depicted in Table 2 below.

Table. 2 Ten elements of student centred learning

\begin{tabular}{ll}
\hline Elements of students & Brief explanation \\
\hline Students and teachers as co-learners & $\begin{array}{l}\text { Teachers do not regard themselves as the all- } \\
\text { knowing people } \\
\text { Student-students interaction }\end{array}$ \\
$\begin{array}{l}\text { Teachers encourage students to have constructive } \\
\text { discussion and sharing }\end{array}$ \\
Learner autonomy & $\begin{array}{l}\text { Teachers promote students independency in } \\
\text { decision making for their own learning }\end{array}$ \\
Focus on meaning & Teachers promote values and essence of the \\
& learning
\end{tabular}




\begin{tabular}{ll}
\hline Curricular integration & $\begin{array}{l}\text { The connection between the lessons and every } \\
\text { day circumstances is clear }\end{array}$ \\
Diversity & $\begin{array}{l}\text { Treatment is dynamic based on the students' } \\
\text { characteristics }\end{array}$ \\
Thinking skills & Teachers promote critical thinking skills \\
Alternative assessment & $\begin{array}{l}\text { Teachers make use of authentic tasks to see the } \\
\text { students' progress }\end{array}$ \\
Learning climate & $\begin{array}{l}\text { More students' participation and initiation to } \\
\text { learn by themselves are realized }\end{array}$ \\
Motivation & Intrinsic motivation dominates
\end{tabular}

\subsection{The Characteristics of SCL}

This study notices at least four major principles that characterize SCL. First, the teaching and learning process addresses the students' diverse learning needs and cultural backgrounds. Second, the students enhance their education through demonstration of their knowledge and skills. Third, the flexibility to learn without time and place limitations can be gained by the students. They can make use of work-study programs or online courses at nights and/or on weekends. Fourth, the students can have opportunities to activate self-regulatory learning and design their own learning trajectories.

In line with the ideas above, O’Neill and McMahon (2005) provide a list of the main principles of SCL, as follows.

- Full responsibility of the students' learning

- Conscious and full involvement and participation

- Manifestation of equal opportunity to succeed

- Facilitative role attached on the teachers

- Affective and cognitive domains confluence to maximize the learning

\subsection{SCL and 2013 Curriculum}

SCL in 2013 Curriculum of English language subject is the continuation for improvement of the previous curriculum and a means of resolving the current existing problems in English teaching and learning process, according to Wachidah (2013). Although the students are being encouraged to have more practical skills, the coherence the four skills of English is untouched. The activities are not integrated yet. Students focus too much on abundance of expressions, not activities. For example, they still focus on forms and words, not discourse. Moreover, the presentation of authentic texts is still limited. Viewed from the learning process, the activities are textbook-driven which lose the opportunity for the students to experience real communication. The teacher's mere role as the learning director and single knowledge resources increases the 
loss of meaningful learning atmosphere since the process depends on the teacher's explanation and homework.

Therefore, SCL comes into the heart of 2013 Curriculum to address the problems. The development of students' communicative competence becomes the ultimate goal. To maximize its process, the students are encouraged to learn English by applying the five stages of scientific approach, i.e. observing, questioning, exploring, associating, and communicating. Those stages are expected to promote the students' critical thinking and decision-making skills. With respect to the learning resources, SCL is translated into the use of authentic texts in the spoken and written fashions from various sources. The goal is to get the students accustomed to not only the real language use but also its application in their daily lives as the purpose of the 2013 English curriculum formulation.

The aforementioned positive points about the implementation of SCL in EFL classroom and the existing mandates from the government will just become written notes if the teachers cannot be the effective agent to implement it. Thus, the teachers need to revisit some of the fundamental roles while maximizing the potentials of SCL in the classroom. As explained by Dornyei (1989), in a language classroom, the teachers must play role as a facilitator. In a student-centered classroom, the less directive they behave, the better the role of facilitator they manifest. Another important role is the imperfect language knower. Their limitations must be accepted critically as teachers and learners simultaneously. It is common that the teachers sometimes feel depressed or worn-out when pretending to have all capabilities to manage the classroom and resolve all of the students' language barriers. However, in the atmosphere of trustfulness and acceptance, such a behavior can be eliminated resulting in the decrease of tensions and burnout.

\section{Research Methodology}

\subsection{Design}

This study is designed as a descriptive qualitative inquiry. It intends to explore the implementation of student-centered learning in EFL classroom from the secondary school teachers' perspectives.

\subsection{Sites and Participants}

The research was conducted involving four schools: two state senior high schools in the area of Bandung City and two private Islamic junior high school in the area of Tangerang City. The purposive selection of the sites aimed to obtain adequate findings related to the phenomenon (Creswell, 2009) because the schools have been implementing 2013 Curriculum for two years. At first, there were nine (9) English teachers as the participants in this study. However, only four (4) teachers who were willing to participate until the follow-up interview because they had already got the training of K-13 and implemented it in their classes. Table 3 depicts the background information of the participants. 
Table 3. Participants' background information

\begin{tabular}{ccccccc}
\hline No & Participants & Gender & $\begin{array}{c}\text { Experience in } \\
\text { Teaching English }\end{array}$ & $\begin{array}{c}\text { K-13 } \\
\text { training }\end{array}$ & $\begin{array}{c}\text { Implementing } \\
\text { K-13 }\end{array}$ & $\begin{array}{c}\text { Length of } \\
\text { implementation }\end{array}$ \\
\hline 1. & T1 & F & 5-10 Years & Yes & Yes & 1 year \\
2. & T2 & F & 10-15 Years & Yes & Yes & 1 year \\
3. & T3 & M & 15-20 Years & Yes & Yes & 1 year \\
4. & T4 & M & 5-10 Years & Yes & Yes & 2 years \\
\hline
\end{tabular}

It shows that all of the teachers had teaching experience ranges from 1 to 20 years. In addition, all of them have got training of the 2013 Curriculum and only one teacher has applied the curriculum more than one year.

\subsection{Instruments and Data Collection Procedures}

Two instruments were used to obtain the data: a close-ended questionnaire and an interview protocol. The questionnaire was adapted from Al-Humaidi (2015) and 2013 Curriculum based on the Regulations of MOEC of Indonesia No. 70A. It was aimed to address the first and second research questions: (1) How do the English language teachers perceive SCL? (2) What kind of SCL strategy do they apply? Specifically, the questionnaire consists of ten (10) statements related to the teachers' roles in their SCL-driven classrooms in which each statement consists of four responses, i.e. Always, Often, Seldom, and Never. The reason why the researchers did not provide 'Sometimes' response was the consideration of getting bias responses from the participants. It was distributed online to all participants in order to find out Indonesian EFL teachers' belief on and attitudes toward SCL within their classes.

After the participants filled in and returned the questionnaire, a follow-up interview was done. The interview protocol consists of two semi-structured questions intended to address the third research question What are the challenges in realizing the SCL approach? The first question seeks to obtain information about their challenges in implementing SCL, and the second question seeks to obtain information about their suggestions or expectations in implementing SCL in the classroom.

\subsection{Data Analysis Procedures}

The obtained data were analyzed and displayed descriptively (Miles \& Huberman, 1994) consisting of three procedures: data reduction, data display, and conclusion drawing/verification. First, the questionnaire data of each statement from each participant were firstly tabulated based on the number of each response. Then, the tabulation results were translated into percentages. Meanwhile, the interview data were all re-typed. The final data were then displayed in the forms of excerpts. In the drawing / data verification procedure, interpretation and conclusion of the data were drawn to answer the research questions and obtain the essence of the present study. 


\section{Findings}

This section consists of three sub-sections that elaborate the findings and the previous literature to address the research questions. Each sub-section addresses one research question sequentially. The following excerpts from the interview were quoted verbatim.

\subsection{RQ 1: How do the English language teachers perceive SCL?}

In this study, perception is defined as what the teachers perceive on the implementation of SCL in 2013 Curriculum in conjunction with their background information. Table 4 provides the details. It showed that most of the teachers had positive perception on SCL because they considered it as an important approach in teaching English in their classroom. This is, however, quite contradicting to the actual practice based on the responses about the students' characteristics. Of the four teachers who answered the question, three teachers argued that the students were still passive in the classroom. The reason might be related to the students' level of English proficiency confirmed by the teachers in which they were still categorized as basic user of English language. Meanwhile, one teacher who argued that the students were active confirmed that the students' English proficiency is intermediate.

Table 4. General information about the teachers' perception on SCL

\begin{tabular}{|c|c|c|c|c|c|}
\hline No. & Item & $\mathrm{T} 1$ & $\mathrm{~T} 2$ & $\mathrm{~T} 3$ & $\mathrm{~T} 4$ \\
\hline 1. & Students' level of English & Basic & Intermediate & Basic & Basic \\
\hline 2. & Students' characteristics & Passive & Active & Passive & Passive \\
\hline 3. & $\begin{array}{l}\text { Understanding the concept and } \\
\text { principles on SCL }\end{array}$ & Yes & Yes & Yes & Yes \\
\hline 4. & Experience in training about SCL & Yes & Yes & Yes & Yes \\
\hline 5. & $\begin{array}{l}\text { Practice SCL approach in the } \\
\text { classroom }\end{array}$ & Yes & Yes & Yes & May be \\
\hline 6. & $\begin{array}{l}\text { State of agreement on the } \\
\text { importance of implementing SCL } \\
\text { in the classroom }\end{array}$ & Yes & Yes & Yes & May be \\
\hline
\end{tabular}

Furthermore, they had basic understanding about the concept of SCL and had obtained SCL training followed by the practice in their classrooms. Interestingly, Teacher 4 expressed an indecisive proposition on the importance of SCL and the agency to implement SCL in the classroom.

\subsection{RQ 2: What kind of SCL strategy do they apply?}

At least, there were three main themes obtained from the questionnaire results. They were: the teachers' strategy to deliver the materials, the teachers' strategy to live the interaction, the teachers' strategy to assign exercise or task. Chart 1 depicts the overall results of the three themes. 


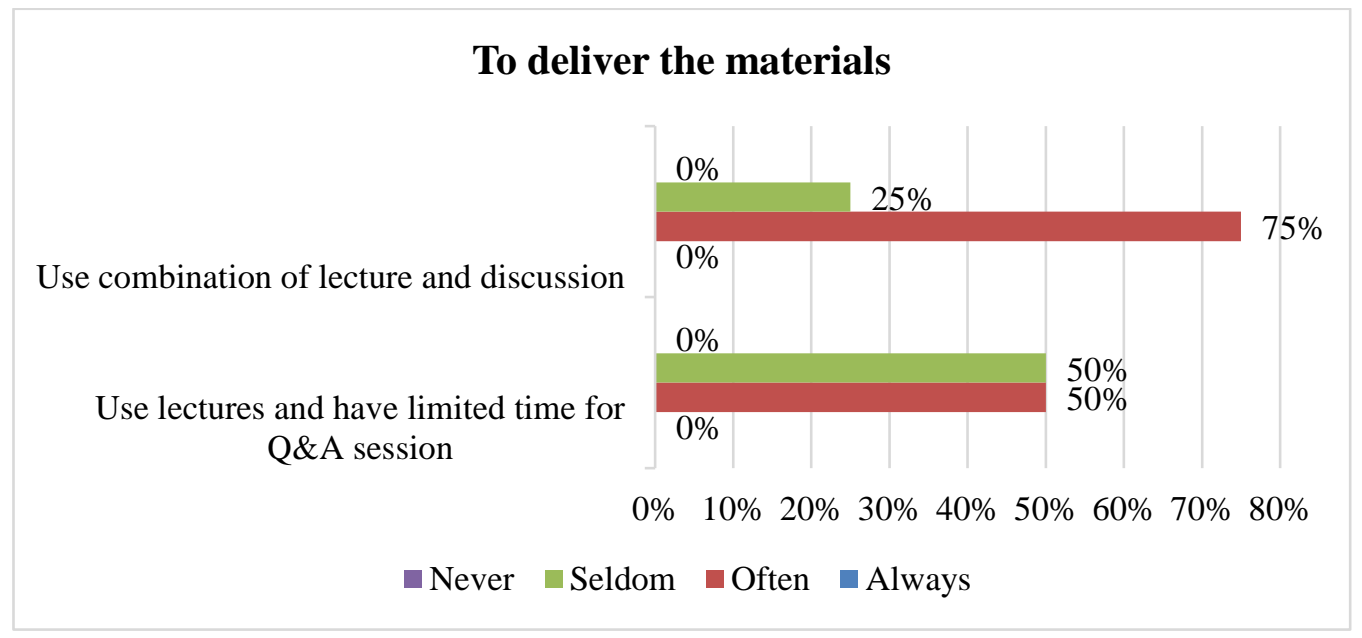

Figure 1. Teacher's style of materials delivery

With respect to the first theme, i.e. to deliver the materials, half of the teachers preferred to use lectures leading to the inadequacy to provide time for the students to have question and answer session. Meanwhile, the other half did not frequently employ such a strategy in teaching English in the classroom. This indicates that the teachers still have a tendency not to open opportunities for the students to ask for clarification or questions about what they might not understand. It may lead to the decrease of active participation as an indicator of the successful implementation of SCL. Although question and answer was not fully carried out in the classroom, most of them are still concerned with the provision of discussion among the students. It can be seen that $75 \%$ of the teachers used a combination of lecture and discussion while delivering the materials. While the other $25 \%$ of the teachers were still used to giving lecture only. It is not surprising considering the consensus regarding the first statement discussed earlier.

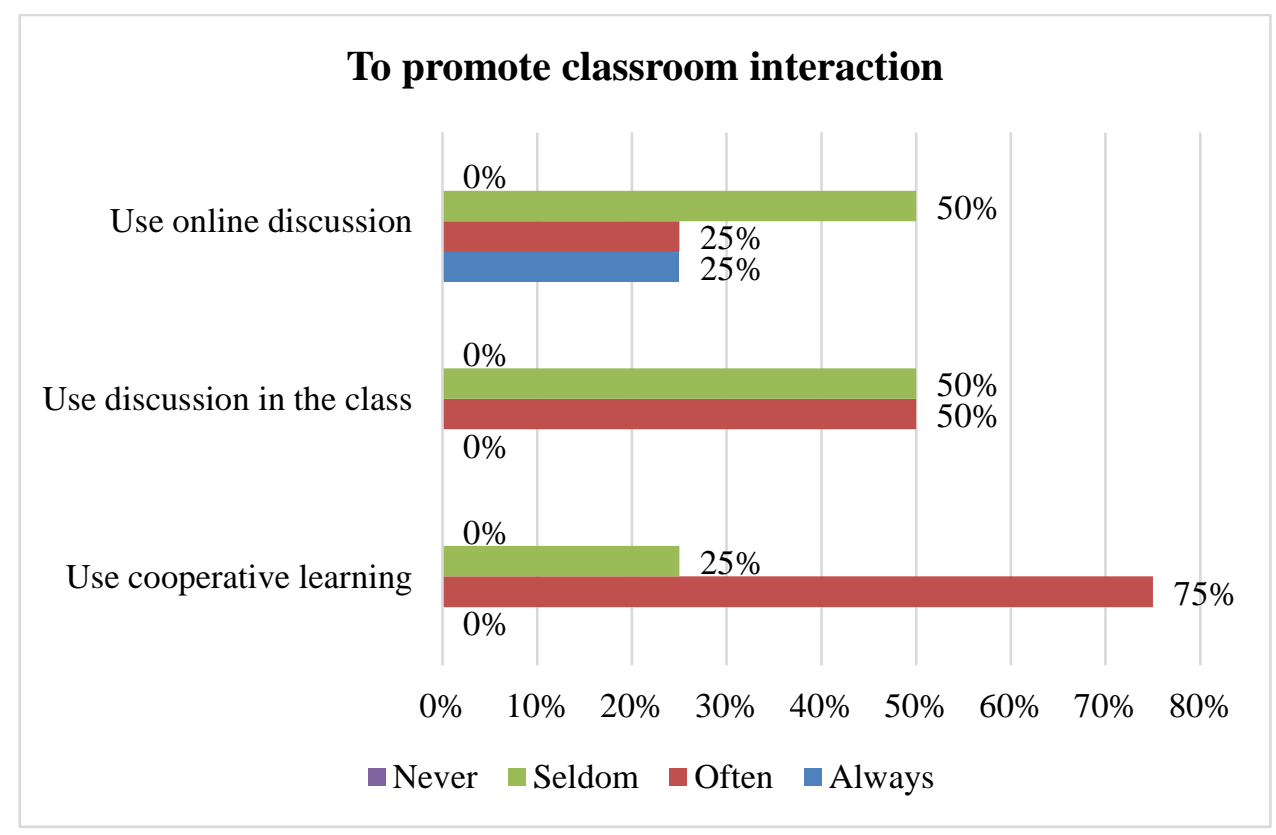

Figure 2. Teacher's style of classroom management 
Furthermore, as another focal indicator of a successful SCL, the way the teachers promote classroom interaction as the second theme needs to be explored. Cooperative learning becomes one of the ways to realize the goal. Most of the teachers confirmed that they preferred to conduct a cooperative learning to live the student-student interaction. Meanwhile, $25 \%$ of them still did not regularize the potential of this kind of learning. This indicates that most of the teachers have been aware of providing equal participation for every single student in the learning process. It is because cooperative learning can not only encourage them to communicate with each other but also promote soft skills like teamwork and personal responsibility that will indirectly increase self-autonomy as the outcome of SCL itself. However, discussion was not preferable among the teachers. Only $50 \%$ of them often used it in the classroom. This strengthens the result of the second statement of the first theme that a combination of lecturer and discussion was routinized more. In addition, the use of online discussion still received little attention from the teachers to be a strategy to implement SCL in the classroom. Only $25 \%$ of them did always use it in promoting the students' interaction.

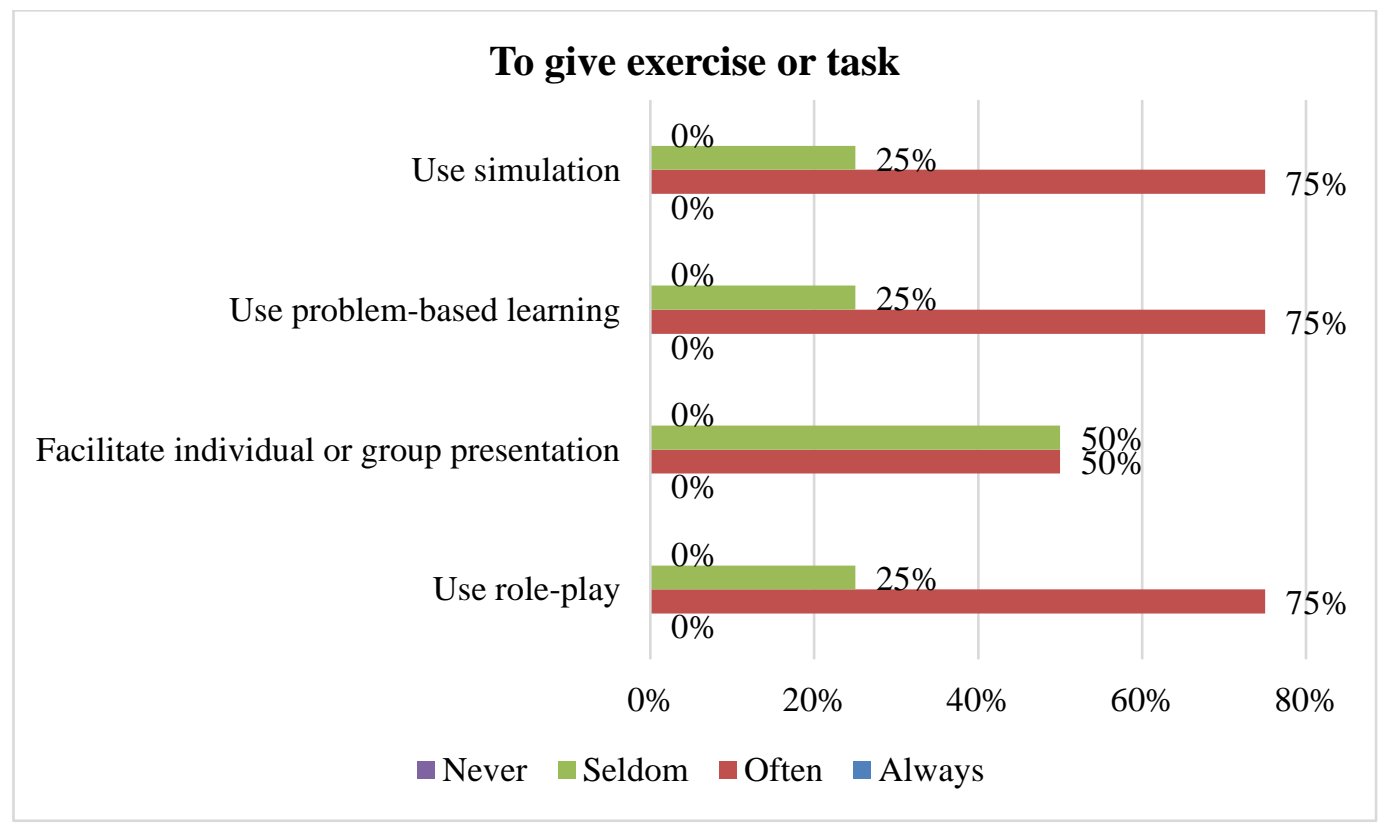

Figure 3. Teacher's style in giving assignment

The last but not least theme is about the teachers' ways of assigning exercise or task. Role play became the first preferable medium for the teachers to encourage the students' activeness while doing an exercise or task in which only $25 \%$ of them seldom initiated this strategy. As another version of role-play, doing simulation was also carried out by the teachers by putting the students in a real situation. Similarly, $75 \%$ of them have regularized it in their classrooms. The third strategy implemented by the teachers was problem-based learning. This enables the students' critical thinking skill as one of the elements in SCL mentioned in the literature review section. However, $25 \%$ of the teachers still did not prefer to use it. Interestingly, a more academic strategy to implement SCL like the facilitation of individual or group presentation was 
in a fifty-fifty situation. Only half of the teachers (50\%) have awareness to frequently involve the students to be knowledge transmitter and developer simultaneously, while the other $50 \%$ seldom did so.

It can be concluded that the values of collaboration and critical thinking have been underscored by the most of the teachers considering the facts that they frequently regularize cooperative learning, role-play, and problem-based learning. However, one limitation was identified because there is no further explanation behind the teachers' choices, particularly on the negligence of facilitation of individual or group presentation compared to other strategies in assigning exercise or task.

\subsection{RQ3: What are the challenges in realizing the SCL approach?}

Only four teachers were willing to participate in the follow-up interview. As most of the teachers relatively just started the implementation of K-13 and shifted from teacher-centered to be more student-centered learning, they encountered some difficulties. Teacher one (T1) dealt with the complexity of implementing SCL in terms of the students' passivity and lack of confidence in using English. T1 asserts,

"Kurang nya kepercayaan diri siswa dalam pelajaran bahasa inggris sehingga siswa pasif disalam kelas, kurangnya jam pelajaran b inggris dlm K13 sehingga guru tidak punya cukup banyak waktu untuk mengasah kepercayaan diri siswa."

[The students are lack of self-confidence in learning English, they became passive in the classroom. In addition, the lack of allocated time for English subject in K-13 made difficult for the teachers to improve their self-confidence.]

Both issues were still dominating the hindrance of succeeding the implementation of SCL in the classroom, so that they need more motivation and encouragement to be more active. Such a challenge is in line with what T1 suggests. SCL should be able to encourage the students to be more active and confident in learning English. The following excerpt represents the suggestion.

"SCL bisa dilaksanakan dgn baik jika siswa mempunyai kepercayaan diri yg baik, sehingga sebaiknya guru, terutama guru bahasa inggris harus mampu membuat metode pembelajaran yang mampu memberikan motivasi dan ransangan agar siswa mau aktif dan kepercayaan diri dalam pembelajaran b Inggris."

[SCL can be carried out well if the students have good self-confidence. Consequently, the teachers should be able to employ the teaching methods, which can promote motivation and give stimuli to the students, so that they become active and confident in learning English.]

Furthermore, as the result of students' passivity and lack of self-confidence, T3 argued that the meaningful communication with the students becomes hardly realized.

'Murid kurang merespon dan kadang sulit untuk berinteraksi." 
[The students respond less and sometimes feel difficult to interact.]

To overcome such a problem, T3 gave a suggestion to teachers who also encounter such a challenge to employ as many learning media as possible. Its use aims to scaffold the students' limited ability to communicate in English step by step. T2 also uttered an alternative solution by informing the students about what they are going to do and what they should do in every learning process. This strategy will make them accustomed to being involved, so that it will indirectly lessen the students' communication difficulty.

Another difficulty experienced by the teachers was the limited allocated time for English subject, which got two hours per week. It results in more challenges to elaborate the topic and manage the implementation of SCL. T2 asserts,

"Waktu yang terbatas seminggu sekali dua jam pelajaran jadi sulit untuk membahas sesuatu secara mendalam dan tuntas"

[The limited time, which is only two hours every week made me difficult to discuss the lesson deeply and thoroughly.]

The last but not least was the assessment system in K-13. T4 argued that due to the new learning principles including the implementation of student-centered learning everything about the students' learning evaluation is changed. It is considered more time consuming and complex. The following excerpt represents the challenge T4 encountered.

"Waktu yg minim utk pelatihan, terutama utk pelatihan penilaian K13 yg cukup merepotkan dan melelahkan."

[The limited time for training, particularly for the K-13 assessment training is quite troublesome and wearing.]

Unfortunately, the way the teacher solved such a challenge in the real practice cannot be obtained. Therefore, T4 further clarified a hope for the government expressed in the following excerpt.

"Perbanyak training utk guru bahasa inggris ttg pengajaran SCL dan penilaian nya, buatlah sistem penilaian yg simple, otomatis dan sederhana."

[Provide more training for the English teachers about the SCL-based teaching and its assessment system. Make the assessment system simple, automatic, and not too rigor.]

It indicates that although SCL-based learning can be implemented by using some strategies, the assessment system for evaluating the students' learning progress is still problematic. This issue is no surprise because regardless of the importance of socialization, they might find it hard to visualize equal assessment rubrics for every single student because the learning process also emphasizes equal opportunity to be better in mastering English language. 


\section{Discussion}

This study attempts to explore the perception of English teachers working in Islamic secondary schools on the SCL implementation based on the 2013 Curriculum framework, their strategies to apply it, and the encountered challenges. It elaborates on the findings of the present study and the previous literature to get the essence of this research.

Most the teachers had a positive view that SCL is pivotal to be applied in the classroom. This is line with Lee's (2009) study in which the participants have full awareness of the importance of SCL. Furthermore, under the scope of integration in accordance to the Regulations of MOEC of Indonesia No. 81A, the findings indicate that SCL is integrated to encourage the students' active, critical, and collaborative participation. This is in line with what is stipulated in the curriculum.

In teaching and learning process should include the principles of (1) students centered learning (2) encouraging students' creativity (3) creating excitements and challenges in learning (4) involving values, ethic, esthetic, and kinesthetic (5) providing experiential learning through varieties of learning strategic and method that is exciting, contextualized, effective and meaningful.

The implementation of SCL by the teachers includes cooperative learning, combination of discussion and lectures, role-play, problem-based learning, and simulation. By those practices, most of the teachers applied the concept of SCL in their classroom which facilitates the students' activeness, independence, and collaborative skills as a team in the classroom.

In addition, we would like to underscore the importance of cooperative learning as a means of promoting SCL in EFL classroom. Previous studies related to the implementation of CL have noted its benefits including increased equal participation, opportunity for success, and group processing (Slavin, 1995; Ning, 2011; Lubis, 2016) manifested in the increased opportunity to initiate discussion and meaning interaction. Those benefits are in line with the goal of SCL itself; that is to promote learner autonomy in learning English, so that they can maximize their own abilities through social-constructivism-based learning activities.

Surprisingly, the findings revealed that $50 \%$ teachers never used online discussion. It shows that the preference of SCL implementation approach in the classroom is not much involving the use of ICT. It conforms to the results obtained by Lubis (2018) that the teachers still did not maximize the learning process by integrating the ICT. This is in contradiction with the principles of 2013 Curriculum, stipulating that the learning process could be anywhere and anytime not only in the classroom.

Another concern in English 2013 Curriculum is about allocated time for English subject. It has only two credit hours. Consequently, it is difficult for the teachers to enhance the students' competences by giving exercises and opportunities to practice English. This shortcoming influences the expected objective of education and the political and economic concerns of the teachers. To enhance the SCL, the teachers need review the current scientific studies about SCL 
and its theoretical development and compare them to the existing challenges in their classrooms, so that a sort of action research for a better implementation of SCL in EFL settings can be realized.

\section{Conclusion}

The data set has addressed three research questions, (1) How do the English language teachers perceive SCL? (2) What kind of SCL strategy do they apply? (3) What are the challenges in realizing the SCL approach? Two conclusions can be drawn. First, most of the teachers perceived the implementation of SCL approach as a helpful means of promoting students' active participation, regardless of the fact that the students' low level of proficiency and activeness. Second, the values of collaboration and critical thinking have been underscored by the most of the teachers considering the facts that they frequently regularize the combination of lecture and discussion, cooperative learning, role-play, and problem-based learning. Third, at least there were three major challenges in implementing the SCL in the EFL classroom: the students' lack of self-confidence leading to lack of courage to communicate in English, lack of allocated time to maximize the facilitation, and lack of training in doing the assessment. Thus, this study might give insight into the body of knowledge about the theory of student-centered learning because the findings extend the consensus of current practices of SCL from the perspectives of Islamic secondary school teachers, which is not explored extensively by the previous studies.

Several limitations were also noticed. First, due to the small-scale participants $(\mathrm{N}=4)$ for the sake of initial exploration, there is an issue of data generalizability. A replication study involving a large-scale participant selection technique might be worth conducting across wider contexts. Second, this study only focused on the teachers' perceptions and attitudes. Hence, the exploration on both aspects of the students as well as the teachers' real practices in the classroom will become an insightful continuum for a better understanding of SCL implementation in EFL classroom settings. Finally, with respect to the identified challenges, there is a need for the encouragement of more training on SCL implementation followed by vertical assistance and monitoring from the government and horizontal ones from the school members, i.e. principal and expert colleagues.

\section{References}

Al-Humaidi, S. (2015). Student-centered learning at Sultan Qaboos University: EFL students' perceptions. International Journal of Education, 7(3), 194-209.

Creswell, J. W. (2009). Research design: Qualitative, quantitative, and mixed methods approaches (3rd ed.). New Delhi: Sage Publication.

Dornyei, Z. (1989). A student-centred approach to language teaching. Retrieved from http://www.zoltandornyei.co.uk/uploads/1989-dornyei-gajdatsy-pet.pdf 
Jacobs G. M., \& Renandya, Willy. A. (2016). Student-centred learning in ELT. Switzerland: Springer.

Lee, S. J. (2009). Exploring students' beliefs about teaching and learning in relation to their perceptions of student-centered learning environments. Retrieved from https://athenaeum.libs.uga.edu/handle/10724/25855

Lubis, A. H. (2016). Literature circles as a facilitator to promote composition process: A voice from tertiary EFL students. Asian EFL Journal, 1, 138-152.

Lubis, A. H. (2018). ICT integration in $21^{\text {st }}$-century Indonesian English language teaching: Myths and realities. Cakrawala Pendidikan, 37(1), 11-21. doi: 10.21831/cp.v37i1.16738.

Miles, B., M \& Huberman., A., M. (1994). Qualitative data analysis (2nd ed.). United States: Sage Publication.

Ning, H. (2011). Adapting cooperative learning in tertiary ELT. ELT Journal, 65(1), 60-70. doi:10.1093/elt/ccq021.

Nur, M. R., \& Madkur, A. (2014). Teachers' voices on the 2013 Curriculum for English instructional activities. Indonesian Journal of English Education, 1(2), 119-134.

O’Neill, G., \& McMahon, T. (2005). Student-centred learning: What does it mean for students and lecturers? In G. O'Neill, S. Moore and B. McMullin (Eds.), Emerging Issues in the Practice of University Learning and Teaching (pp. 27-36). Dublin: AISHE.

Slavin, R. E. (1995). Cooperative learning: Theory, research, and practice (2nd ed.). Needham Heights: Allyn and Bacon.

The Ministry of Education and Culture of Indonesia. (2013). Implementasi kurikulum (no. 81A). Jakarta, Indonesia: Author.

The Ministry of Education and Culture of Indonesia. (2013). Mindset implementasi Kurikulum 2013 (no. 70A). Jakarta, Indonesia: Author.

Wachidah, S. (2013). 2013 English Curriculum. Paper presented at Seminar and Workshop on the 2013 English Curriculum, Bogor Ibn Khaldun University. 